ORIGINAL ARTICLE

\title{
Is it possible to predict the blood volume of a sick preterm infant?
}

\author{
N Aladangady, T C Aitchison, C Beckett, B M Holland, B M Kyle, C A J Wardrop
}

Arch Dis Child Fetal Neonatal Ed 2004;89:F344-F347. doi: 10.1136/adc.2003.039008

See end of article for authors' affiliations .....................

Correspondence to: Dr Aladangady, Neonatal Unit, Homerton University Hospital, London E9 6SR, UK; N.Aladangady@qmul. ac.uk

Accepted 24 July 2003
Objective: To investigate the relation between the measured intravascular blood volume (BV) and current methods of indirectly assessing BV status in sick preterm infants on the first day of life.

Methods: Thirty eight preterm infants of gestation 24-32 weeks (median 30) and weight 480-2060 g (median 1220) were studied. Red cell volume was measured by the fetal haemoglobin dilution method in six infants and by the biotin labelled autologous red cell dilution method in the remaining 32. Total BV was calculated by dividing red cell volume by packed cell volume. Indirect assessments of BV status using heart rate $(H R)$, core-peripheral temperature difference, mean arterial pressure, base excess, and packed cell volume were recorded.

Results: The mean (SD) initial measured BV was 71 (12) $\mathrm{ml} / \mathrm{kg}$ (range 53-105). The mean HR was 148 beats/min (range 130-180), which correlated positively $(r=0.39, \mathrm{p}=0.02$ ) with BV (higher HR was associated with higher BV). The mean base excess was $-3.19 \mathrm{mmol} / \mathrm{l}$ (range -18 to +6.2 ). The negative base excess correlated significantly positively $(r=0.41, p<0.01$ ) with BV (more acidotic babies tended to have higher BV). There was no significant correlation between core-peripheral temperature difference, mean arterial pressure, or packed cell volume and BV. Regression analysis showed that base excess and HR were significantly related to BV; base excess alone can predict variability in BV only to $17 \%$, and base excess with HR can predict variability in BV to $29 \%$.

Conclusion: The conventional clinical and laboratory indices are poor predictors of measured blood volume.
T he clinical question often arises "does the sick preterm infant need volume expansion or fluid restriction?" It has been suggested that it would be easier to sort out which intravenous fluid to use for volume expansion than to decide to whom it should be given and when. ${ }^{1}$ There is widespread clinical acceptance of the rather simplistic concept that hypovolaemia can be suspected from a combination of hypotension, tachycardia, falling packed cell volume (PCV), and metabolic acidosis. However, Ebert et al have shown that, in healthy adult volunteers, clinical symptoms or signs of hypovolaemia are not seen despite the loss of up to 15-20\% of total blood volume (BV), even on rapid removal of the blood within 6-13 minutes. Shippy et al have reported that, in critically ill adults, the commonly monitored variables such as mean arterial pressure (MAP), central venous pressure, pulmonary artery wedge pressure, heart rate (HR), PCV, and cardiac output are not of themselves reliable reflections of intravascular volume status.

Haematological variables involved in oxygen delivery ${ }^{4}$ include haemoglobin concentration or PCV, red cell volume (RCV), and BV. In sick infants with impairment of capillary integrity, RCV and plasma volume tend to fall and fluctuate because of extravasation of components of the plasma, so BV cannot be predicted accurately from PCV/haemoglobin concentration. ${ }^{6}$ In preterm infants, BV strongly influences the development of postnatal lung function ${ }^{7}$ and outcome. ${ }^{8-10}$

The aim of this study was to find out whether the current methods of indirect assessment of BV status in sick preterm infants correspond with the directly measured intravascular volume.

\section{PATIENTS AND METHODS}

Thirty eight babies born in The Queen Mother's Hospital, Glasgow were included in the study. The median gestational age of the study population was 30 weeks (range 24-32), and median birth weight was $1220 \mathrm{~g}$ (range 480-2060). The mode of delivery was caesarean section in 19 infants ( 11 male) and vaginal in 19 infants ( 9 female). Antepartum haemorrhage had occurred in 10 cases. The time of clamping of the umbilical cord was variable (10-90 seconds). Twenty infants were ventilated (median oxygen 50\% (21-95\%)), six were receiving nasal continuous positive airway pressure (median oxygen $21 \%(21-40 \%)$ ), and the rest were stable in air or low flow oxygen. One infant was receiving dopamine, four received plasma protein solution (for poor perfusion), and five received fresh frozen plasma (in three cases for poor perfusion and in two cases for deranged coagulation) within four hours of birth. None of the infants had received blood transfusion or colloid infusion before BV measurement and collection of the clinical and laboratory indices. Thirty five infants had blood cultures performed soon after birth but all proved negative. The study was approved by the hospital ethics committee; informed written parental consent was obtained.

\section{Measurement of BV}

RCV was measured using the fetal haemoglobin dilution method ${ }^{11}$ in six babies receiving blood transfusion, and by the biotin labelled autologous red cell dilution ${ }^{12}$ method in the remaining 32 babies. RCV was measured within six hours of birth in 33 infants and within 24 hours in the rest. Total BV was calculated by dividing RCV by PCV determined using a venous or arterial sample within four hours of birth.

The highest documented core-peripheral temperature differences (c-pT), HR, and base excess and the lowest recorded intra-arterial MAP during the first six hours were

Abbreviations: BV, blood volume; c-pT, core-peripheral temperature difference; HR, heart rate; MAP, mean arterial pressure; PCV, packed cell volume; RCV, red cell volume 
used. The base excess was estimated on arterial, capillary, and venous blood in 21,14 , and 3 infants respectively.

\section{Statistical analysis}

The dependence between each of the potential explanatory variables (HR, c-pT, MAP, base excess, and PCV) and BV was measured by Pearson's sample correlation coefficient and assessed for significance by the corresponding $t$ test of zero correlation. Stepwise multiple regression using both forward and backward variable selection techniques was used to identify which, if any, of these potential explanatory variables could be used collectively to predict BV.

\section{RESULTS}

The mean (SD) initial BV was 71 (12) ml/kg (range 53-105). Mean HR was 148 beats/min (range 130-180). HR correlated positively with BV; higher HR was associated with higher BV (table 1, fig lA). The mean base excess was $-3.19 \mathrm{mmol} / \mathrm{l}$ (range -18 to +6.2 ). The negative base excess correlated significantly positively $(r=0.41, \mathrm{p}<0.01)$ with BV (fig 1D, table 1); more acidotic babies tended to have higher BV. The c-pT ranged from 0.5 to $3{ }^{\circ} \mathrm{C}$ (mean (SD) $\left.1.28(0.7)\right)$. Intraarterial MAP ranged from 27 to $50 \mathrm{mmHg}$ (mean 39). The PCV at birth ranged from 0.4 to 0.68 (mean 0.5). There was no significant correlation between c-pT, MAP, or PCV and BV (table 1, figs 1B,C,E).

Stepwise multiple regression analysis showed that the base excess and HR were significantly related to BV. The base excess on its own explains $17 \%$ of the variability in $\mathrm{BV}$, and this was only increased to $29 \%$ when HR and base excess were used together. On further analyses excluding two observations with large BV, even the HR $(r=0.10, \mathrm{p}=0.56)$ and base excess $(r=21, p=0.23)$ lose the significant correlation with BV.

\section{DISCUSSION}

Commonly monitored variables such as MAP, HR, base excess, and PCV are necessary for the management of sick
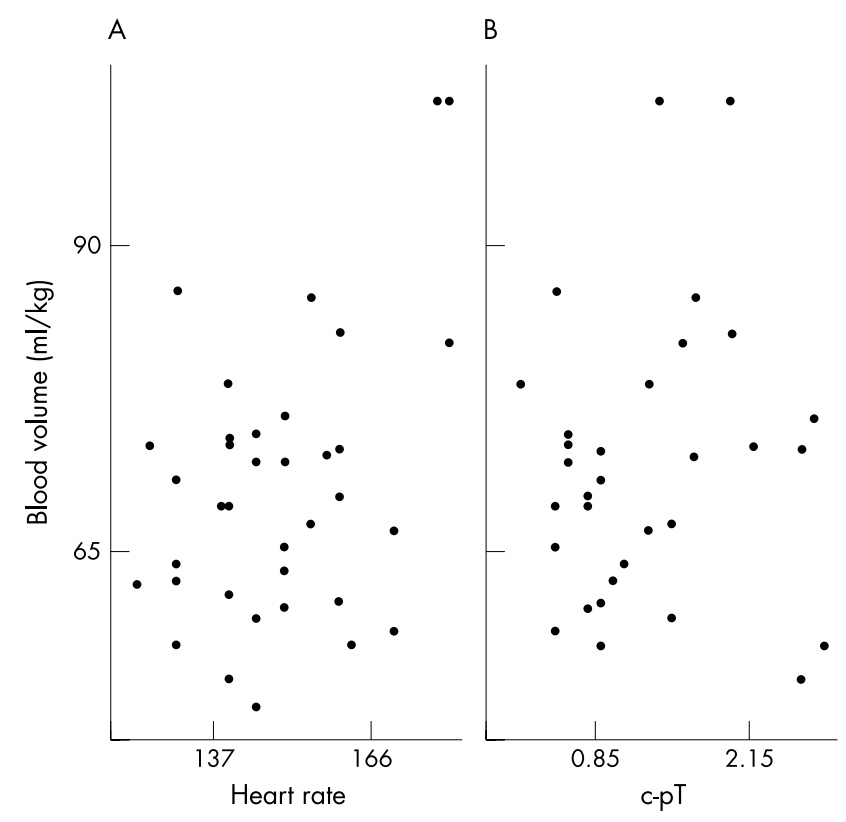

C

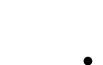

Figure 1 Plots of blood volume against each of the potential explanatory

- variables. c-pT, Core-peripheral

temperature difference; MAP, mean arterial pressure; PCV, packed cell volume.

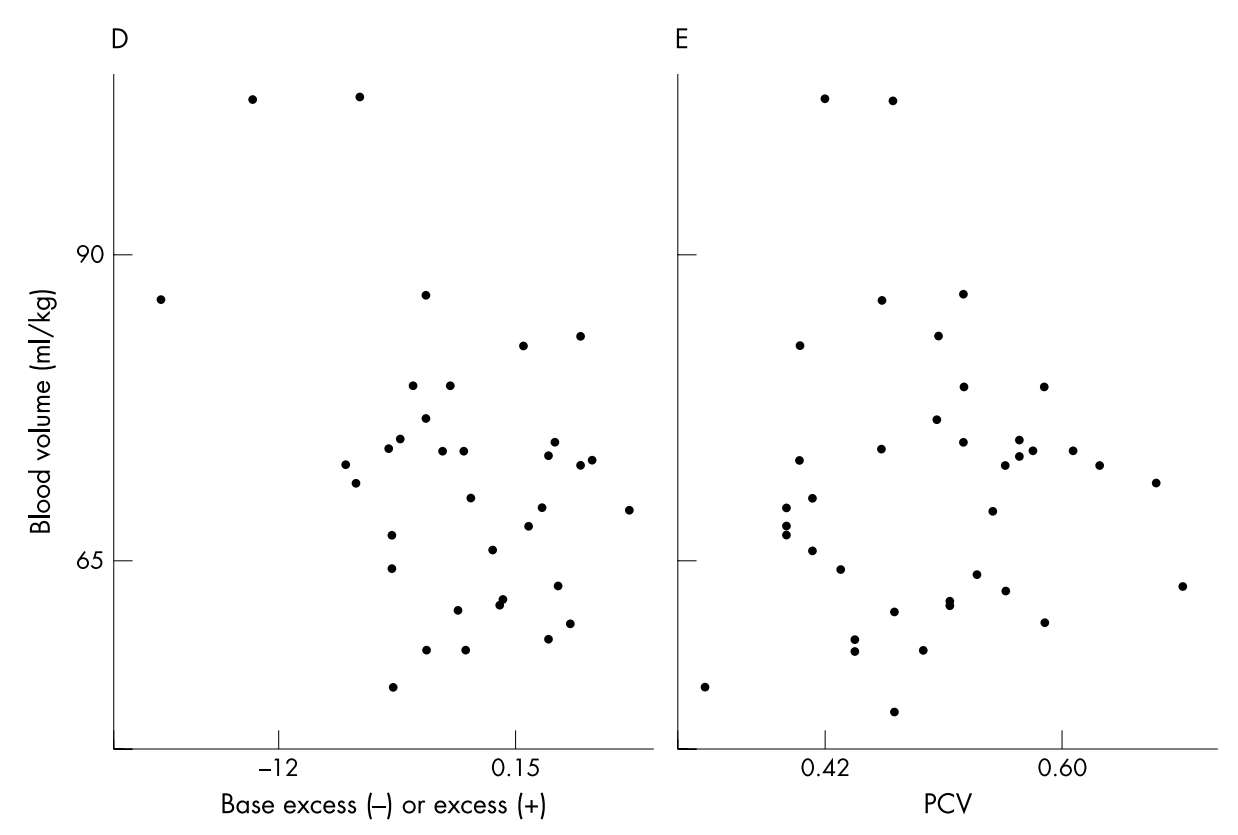


Table 1 Summary statistics and correlations with blood volume of potential explanatory variables

\begin{tabular}{lll}
\hline Variable & $\begin{array}{l}\text { Sample } \\
\text { mean (SD) }\end{array}$ & $\begin{array}{l}\text { Sample correlation with } \\
\text { blood volume (p value) }\end{array}$ \\
\hline $\mathrm{HR}($ beats $/ \mathrm{min})$ & $148(15)$ & $0.39(0.02)$ \\
$\mathrm{c-pT}\left({ }^{\circ} \mathrm{C}\right)$ & $1.28(0.73)$ & $0.08(0.66)$ \\
$\mathrm{MAP}(\mathrm{mm} \mathrm{Hg})$ & $38.7(7.5)$ & $-0.05(0.80)$ \\
$\mathrm{BE}(\mathrm{mmol} / \mathrm{I})$ & $-3.19(4.10)$ & $0.41(<0.01)$ \\
$\mathrm{PCV}$ & $0.496(0.081)$ & $0.03(0.87)$ \\
\hline
\end{tabular}

$H R$, Heart rate; c-pT, core-peripheral temperature difference; $M A P$, mean arterial pressure; $B E$, base excess; $P C V$, packed cell volume.

preterm infants. The data from this study show that they do not predict measured BV at all well. PCV, which represents a ratio of red cells to plasma in the blood, correlates with RCV in healthy subjects. However, not only after acute blood loss, but also in many sick patients with impairment of capillary integrity, plasma volume fluctuates and falls because of extravasation of plasma components, and so BV cannot be accurately predicted from PCV. ${ }^{5}{ }^{12}$

The mean BV of the preterm infants in this study was low, $71 \mathrm{ml} / \mathrm{kg}$ (predicted normal $>90 \mathrm{ml} / \mathrm{kg}$ ). ${ }^{513}$ Published data on BV of preterm infants of 24-32 weeks gestation are negligible. Mollison et $a l^{14}$ reported that the average BV was $84.7 \mathrm{ml} / \mathrm{kg}$ (range 68.5-100.3) using a ${ }^{51} \mathrm{Cr}$ labelled red cell method in full term healthy babies within 24 hours of birth. Nelle et $\mathrm{al}^{15}$ comparing BV in full term babies whose umbilical cords were clamped either early or after a delay found mean (SD) values of 70 (9) $\mathrm{ml} / \mathrm{kg}$ (early) and 90 (8) $\mathrm{ml} / \mathrm{kg}$ (delayed). This was based on measured placental residual BV deducted from an assumed total fetoplacental BV of $115 \mathrm{ml} / \mathrm{kg}$. Leipala et al $^{16}$ studied preterm infants born at 26-31 weeks gestation who needed blood transfusions, and reported that BV was 70 (9) $\mathrm{ml} / \mathrm{kg}$ in appropriately grown babies $(\mathrm{n}=6)$ and 70 (16) $\mathrm{ml} / \mathrm{kg}$ in babies who were small for gestational age $(\mathrm{n}=17)$.

Hypovolaemia may cause tachycardia and metabolic acidosis in children and adults. However, we found no clinically helpful correlation between BV and HR or base excess. Leipala $e a^{16}$ also found no correlation between HR and BV in preterm infants who had been judged to need blood transfusion. Theye and Tuohy ${ }^{17}$ reported that there was no correlation between BV and HR in adult patients undergoing major surgery. It is interesting to note that none of the babies in this study with low BV had negative base excess $>8$, but two babies with normal BV had a negative base excess of $>10$. Most did not have negative base excess values that would cause clinical concern in spite of having low BV. There are no comparative published data correlating BV and base excess.

There was no correlation between BV and c-pT in this study. Lambert et al ${ }^{18}$ reported moderate correlation between plasma arginine vasopressin concentration and c-pT, but no correlation between plasma arginine vasopressin and blood pressure before and after volume expansion in preterm infants. Our findings are similar to other reports in which there was no correlation between c-pT and haemodynamic variables such as cardiac index, central venous pressure, systemic vascular resistance index, stroke volume index, or lactate concentration in children and adults undergoing intensive care. ${ }^{19-22}$ It has been suggested that management of shock using temperature gradient as a measure of the patient's haemodynamic status is irrational and may be unsafe. ${ }^{19} 21$

PCV did not predict BV well in this study. Babies with PCV of $0.41 \mathrm{had}$ BV ranging from 50 to $105 \mathrm{ml} / \mathrm{kg}$ (fig $1 \mathrm{E}$ ), and this accords with findings in previous reports. ${ }^{811}{ }^{12}$ There was no correlation between BV and blood pressure in this study, but Linderkamp et $a^{23}$ found a weak correlation between BV and blood pressure in a combined group of preterm and term infants. However, it is well documented that clinical hypotension appears only when there has been substantial volume loss. ${ }^{24}$

Measuring BV by the fetal haemoglobin dilution method ${ }^{11}{ }^{12}$ and the biotin labelled autologous red cell dilution method ${ }^{25-27}$ has been well validated. However, studies of reproducibility and repeatability of these methods of BV measurement in human subjects have not been described because of ethical and practical constraints. Many validated BV methods have been reported in physiological studies of the circulation, despite this inevitable limitation. ${ }^{14} 162829$ The methods reported here are technically complex and time consuming, hence not practical for routine clinical use. Measurement of BV by the fetal haemoglobin dilution technique is applicable when a baby receives a blood transfusion, but cannot be used after one or two transfusions as autologous fetal haemoglobin is replaced.

Thirty three infants had BV measured during the six hour period of surrogate clinical monitoring data collection. In infants whose BV was determined between six and 24 hours after birth, the measured BV may not represent the exact circulating $\mathrm{BV}$ at the time that the rest of the data were collected-that is, during the first six hours. However, there was no clinical evidence of oedema, suggesting no significant capillary leak, and insensible water loss would have been minimised by nursing in closed humidified incubators. The recorded $\mathrm{BV}$ for these babies is the sum of the measured $\mathrm{BV}$ and the volume of sampling blood loss from birth until the time of BV measurement.

It could be argued that values of about $70 \mathrm{ml} / \mathrm{kg}$ may be sufficient for this study population, thus explaining the lack of clear impact of measured "low" BV on the commonly monitored variables used for assessment of intravascular volume status. However, recalling that, in healthy subjects, $\mathrm{BV}$ expressed per $\mathrm{kg}$ lean body mass is $100 \mathrm{ml}$, one must question seriously the adequacy of such a striking discrepancy in these relatively hypovolaemic critically ill infants. The question remains do such BV values represent a threat to the sick preterm infant's circulation, tissue perfusion, and outlook?

\section{CONCLUSION}

Our ability to assess BV using conventional clinical and laboratory evaluation is poor.

\section{ACKNOWLEDGEMENTS}

We are grateful to the medical and nursing staff of the Neonatal Unit at The Queen Mother's Hospital, Glasgow, for their willing cooperation with this study. We thank Mrs B Montgomery for typing the manuscript. We also thank "Well-Being" for their invaluable financial assistance.

\section{Authors' affiliations}

N Aladangady, B M Holland, The Queen Mother's Hospital, Yorkhill, Glasgow, Scotland, UK

T C Aitchison, C Beckett, University of Glasgow, Glasgow

B M Kyle, Western Infirmary, Glasgow

C A J Wardrop, University of Wales College of Medicine, Cardiff, Wales, UK

\section{REFERENCES}

1 Hope P. Pump up the volume? The routine early use of colloid in very preterm infants. Arch Dis Child Fetal Neonatal Ed 1998;78:F163-5.

2 Ebert RV, Stead EA, Gibson JG. Response of normal subjects to acute blood loss: with special reference to the mechanism of restoration of blood volume. Arch Intern Med 1941;68:578-90.

3 Shippy CR, Appel PL, Shoemaker WC. Reliability of clinical monitoring to assess blood volume in critically ill patients. Crit Care Med 1984;12:107-12. 
4 Wardrop CAJ, Jones JG, Holland BM. Detection, correction and ultimate prevention of anaemias in the preterm infant. Transfus Sci 1991;12:257-70.

5 Jones JG, Holland BM, Hudson IRB, et al. Total circulating red cells versus haematocrit as the primary descriptor of oxygen transport by the blood. Br J Haematol 1990;76:288-94.

6 Wardrop CAJ, Holland BM, Jacobs S, et al. Optimisation of the blood for oxygen transport and tissue perfusion in critical care. Postgrad Med J 1992;68:2-6

7 Jaykka S. Capillary erection and the structural appearance of fetal and neonatal lungs. Acta Paediatr 1958;47:484-500.

8 Faxelius G, Raye J, Gutberlet R, et al. Red cell volume measurements and acute blood loss in high-risk newborn infants. J Pediatr 1977;90:273-81.

9 Linderkamp $\mathrm{O}$, Versmold $\mathrm{HT}$, Fendel $\mathrm{H}$, et al. Association of neonatal respiratory distress with birth asphyxia and deficiency of red cell mass in premature infants. Eur J Pediatr 1978;129:167-73.

10 Hudson IR, Holland BM, Jones JG, et al. First-day total circulating red cell volume (RCV) predicts outcome in preterm infants (PTI) [abstract]. Pediatr Res 1990;27:209(A).

11 Phillips HM, Holland BM, Moiz AA, et al. Determination of red cell mass in assessment and management of anaemia in babies needing blood transfusion. Lancet 1986;19:882-4.

12 Hudson IRB, Cavill IAJ, Cooke A, et al. Boitin labeling of red cells in the measurement of red cell volume in preterm infants. Pediatr Res 1990;28:199-202.

13 Wardrop CAJ, Jones JG, Holland BM. In: Gluckman P, Heymann M, eds. Paediatrics and perinatology: the scientific basis. London: Edward Arnold 1996:868-76.

14 Mollison PL, Veall N, Cutbush M. Red cell and plasma volume in newborn infants. Arch Dis Child 1950;25:242-53.

15 Nelle M, Zilow EP, Kraus M, et al. The effect of Leboyer delivery on blood viscosity and other haemorheologic parameters in term neonates. Am J Obste Gynaecol 1993;169:189-93.

16 Leipala JA, Talme M, Viitala J, et al. Determination of neonatal bloodvolume with the haemoglobin subtype method in appropriately grown and growth retarded preterm infants [abstract]. Pediatr Res 1999;45:206A.

17 Theye RA, Tuohy GF. Haemodynamics and blood volume during operation with ether anaesthesia and unreplaced blood loss. Anesthesiology 1964;25:6-13.
18 Lambert HJ, Baylis PH, Coulthard MG. Central-peripheral temperature difference, blood pressure and arginine vasopressin in preterm neonates undergoing volume expansion. Arch Dis Child Fetal Neonatal Ed 1998;78:F43-5.

19 Ryan CA, Soder CM. Relationship between core/peripheral temperature gradient and central haemodynamics in children after open heart surgery. Crit Care Med 1989:17:638-40

20 Tibby SM, Hatherill M, Murdoch IA. Capillary refill and core-peripheral temperature gap as indicators of haemodynamic status in paediatric intensive care patients. Arch Dis Child 1999;80:163-6.

21 Woods I, Wilkins RG, Edwards JD, et al. Danger of using core/peripheral temperature gradient as a guide to therapy in shock. Crit Care Med 1987; 15:850-2.

22 Bailey JM, Levy JH, Kopl MA, et al. Relationship between clinical evaluation of peripheral perfusion and global haemodynamics in adults after cardiac surgery. Crit Care Med 1990;18:1353-6.

23 Linderkamp O, Strohhacker I, Versmold HT, et al. Peripheral circulation in the new born: interaction of peripheral blood flow, blood pressure, blood volume and blood viscosity. Eur J Pediatr 1978;129:73-81

24 Baver R, Hoyer D, Walter B, et al. Changed systemic and cerebral haemodynamics and oxygen supply due to gradual haemorrhagic hypotension induced by an external PID-controller in newborn swine. Exp Toxicol Pathol 1997;49:469-76.

25 Cavill I, Trevett D, Fisher J, et al. The measurement of the total volume of red cells in man: a non-radioactive approach using biotin. Br J Haematol 1988;70:491-3.

26 Mock DM, Lankford GL, Burmeister LF, et al. Circulating red cell volume and red cell survival can be accurately determined in sheep using the $\left[{ }^{14} \mathrm{C}\right]$ cyanate label. Pediatr Res 1997:41:916-21.

27 Mock DM, Lankford GL, Widness JA, et al. Measurement of circulating red blood cell volume using biotin-labeled red cells: validation against ${ }^{51} \mathrm{Cr}$ labeled red cells. Transfusion 1999;39:149-55.

28 Anthony MY, Goodall SR, Papouli M, et al. Measurement of plasma volume in neonates. Arch Dis Child 1992;67:36-40.

29 Mock DM, Bell EF, Lankford GL, et al. Haematocrit correlates well with circulating red blood cell volume in very low birth weight infants. Pediatr Res $2001 ; 50: 525-31$. 